原著

\title{
脳神経外科診療の実績作りに脳血管内治療医は 貢献しているか?
}

\begin{tabular}{|c|c|c|c|}
\hline 和田 & 始 & 櫻井 & 寿郎 ${ }^{2}$, 上森 \\
\hline 折本 & 亮介 1 & 広島 & 覚 ${ }^{1}$ 三井 \\
\hline & 正夫 ${ }^{1}$ & 安栄 & 良悟 ${ }^{1}$, 鎌田 \\
\hline
\end{tabular}

\section{Contribution of the Neuro-endovascular Physicians to Improvement in Neurosurgical Operations}

\author{
Hajime WadA, M.D., ${ }^{1}$ Jyurou SAKuraI, M.D., ${ }^{2}$ Genki Uemori, M.D., ${ }^{1}$ \\ Ryousuke Orimoto, M.D., ${ }^{1}$ Satoru Hiroshima, M.D., ${ }^{1}$ Nobuyuki Mitsui, M.D., ${ }^{1}$ \\ Masao SATou, M.D., ${ }^{1}$ Ryougo AnNeI, M.D., ${ }^{1}$ and Kyousuke Kamada, M.D. ${ }^{1}$ \\ ${ }^{1}$ Depratment of Neurosurgery, Asahikawa Medical University, and ${ }^{2}$ Department of \\ Neurosurgery, Moriyama Hospital, Asahikawa, Hokkaido, Japan
}

\begin{abstract}
Summary: The last 10 years, neuro-endovascular treatment has been widely accepted and is becoming more popular, both because devices have become more developed and because the treatment is supported by evidence.

Our neurosurgical department at Asahikawa Medical University Hospital exists in a city with a population of 360,000 . Although the department has had two physicians with Japanese neuroendovascular board certification for 10 years, both of them were absent for two years (between 2007 and 2009).

We divided a recent 10 -year period into two periods: when the endovascular physicians were present and when they were not to investigate clinical activities and practical operations such as the number of treatments, surgical time and number of admissions.

The total number of operations was 1,871 . The period when the neuro-endovascular physicians were there (60 months) had 916 cases, and the other periods (78 months) had 955 cases. The number of cases of neuro-endovascular treatment was 145 and 41, respectively. During the period with the physicians, not only the total number of endovascular treatments, but also the average monthly case volume of all neurosurgical operations increased significantly. The surgical time for cerebral aneurysm and cervical carotid stenosis was significantly shorter with endovascular treatment than open surgery.

The existence of neuro-endovascular physicians increases the efficiency of neurosurgical treatment and stimulates department activity.
\end{abstract}

\author{
Key words: \\ - neuro-endovascular \\ treatment \\ - neurosurgery \\ - department management
}

Surg Cereb Stroke

(Jpn) 40: 317-321, 2012

\footnotetext{
${ }^{1}$ 旭川医科大学 脳神経外科, ${ }^{2}$ 森山病院 脳神経外科(受稿日 2011.12.20) (脱稿日 2012.3.23)〔連絡先： $\mathbf{T} 078-8510$ 北海道旭川市緑ヶ 丘東 2 条 1 丁目 1-1 旭川医科大学 脳神経外科 和田 始] [Address correspondence: Hajime WADA, M.D., Department of Neurosurgery, Asahikawa Medical University, 2-1 1-1 Midorigaokahigashi, Asahikawa, Hokkaido 780-8510, Japan]
} 
Table 1 Numbers of cases per month with and without endovascular physician

\begin{tabular}{lccc}
\hline & $\begin{array}{c}\text { Endovascular } \\
\text { physician (-) }\end{array}$ & $\begin{array}{c}\text { Endovascular } \\
\text { physician (+) }\end{array}$ & $\mathrm{p}$ \\
\hline $\begin{array}{l}\text { Total endovascular } \\
\text { treatments }\end{array}$ & $0.52 \pm 0.75$ & $2.41 \pm 1.54$ & $\mathrm{p}<0.0001$ \\
\hline Clipping & $1.10 \pm 0.95$ & $0.95 \pm 0.89$ & $\mathrm{p}=0.338$ \\
\hline Clipping and coil & $1.14 \pm 0.95$ & $1.98 \pm 1.20$ & $\mathrm{p}<0.0001$ \\
\hline $\begin{array}{l}\text { Total neurosurgical } \\
\text { operations }\end{array}$ & $12.2 \pm 3.9$ & $15.3 \pm 3.9$ & $\mathrm{p}<0.0001$ \\
\hline $\begin{array}{l}\text { Total neurosurgical } \\
\text { admission patients }\end{array}$ & $784.6 \pm 111.9$ & $782.6 \pm 141.7$ & $\mathrm{p}=0.463$ \\
\hline
\end{tabular}

(Numbers of cases/month, Student t)

はじめに

脳血管内治療は, 1997 年に脳動脈瘤用の Guglielmi detachable coil (GDC)が保険収載となり本格的に日本に 導入された. その後徐々に deviceの進歩, evidence の獲 得に伴い, この領域の地位を確立するとともに広く普及し た. 当施設でも 2001 年から 2 名が臨床海外留学, その後 日本脳神経血管内治療学会専門医取得プロトコールにのっ とり研修, 専門医取得を終え脳神経外科診療に血管内治療 医が加わった. しかし現在まで, 諸般の事情により常勤医 としてチーム診療ができなかった時期があった.

そこで, 人口 36 万人の小都市にある大学附属病院の 10 年間で, 血管内治療医がいた時期といなかった時期で, 診 療科としての activity を比較するため脳血管内治療数, 脳 神経外科全体の手術件数, 入院患者数を検討した. さらに 代表的な治療対象である脳動脈瘤の治療数, その内訳を在 籍した時期，しない時期 4 つに分け検討した.

\section{対象}

対象期間は, 2000 年 1 月から 2011 年 6 月までの 138 か 月間において血管内治療医在籍時不在籍時で比較した。さ らにこの間を当初の不在時期と, 当医局員 2 人がフランス ロスチャイルド病院脳血管内治療臨床留学から帰国し, 1 例目の頝部内頝動脈ステント留置術 (carotid artery stenting: 以下 CAS) を行った 2004 年 1 月〜 2007 年 9 月を在籍 時期とし，その後 2 名とも退職した期間 2007 年 10 月〜 2010 年 3 月を経て, 脳神経血管内治療学会専門医が復職 した 2010 年 4 月以降の 4 つの時期に分け検討した. 当施 設内に血管内治療医が不在時にも, 関連施設の脳血管内専 門医を招聘し, 脳血管内治療は行われていた，2群間の比 較に, Student $\mathrm{t}$ 検定, 多群間の検定に single-factor ANOVAによる統計学的解析を行った.
結果

\section{血管内治療医の不在, 在籍時の比較}

この期間の総手術数は 1,871 件, 脳血管内治療医在籍時 916 件, 不在時 955 件. 脳血管内治療数は血管内治療医在 籍時 145 例, 不在時 41 例であった. 脳血管内治療医不在時, 在籍時に分け脳血管内治療数, クリッピング数, クリッピ ングとコイル塞栓術数を合わせた脳動脈瘤治療数, 脳神経 外科の全手術数, 脳神経外科の入院患者数を比較した (Table 1). 脳血管内治療医在籍時に, 脳血管内治療数が 多かった (血管内専門医不在時期 $0.52 \pm 0.75 /$ 月, 在籍時 期 $2.41 \pm 1.54$ /月, $\mathrm{P}<0.0001$, Student $\mathrm{t}$ 検定). また, この 2 つの時期でクリッピング術数に有意差は認めなかっ たが (血管内専門医不在時期 $1.10 \pm 0.95 /$ 月, 在籍時期 0.95 \pm 0.89 月, $\mathrm{P}=0.338$, Student $\mathrm{t}$ 検定), クリッピングと コイル塞栓術を合わせた脳動脈瘤治療数は脳血管内治療医 在籍時に多かった (血管内専門医不在時期 $1.14 \pm 0.95$ /月, 在籍時期 $1.98 \pm 1.20$ /月, $\mathrm{P}<0.0001$, Student $\mathrm{t}$ 検定 $)$. 同様に脳神経外科の全手術数も両群間に有意差を認めたが (血管内専門医不在時期 $12.2 \pm 3.9$ /月，在籍時期 $15.3 \pm$ $3.9 /$ 月, $\mathrm{P}<0.0001$, Student $\mathrm{t}$ 検定), 全脳神経外科入院 患者数には有意差を認めなかった(血管内専門医不在時期 $784.6 \pm 111.9 /$ 月，在籍時期 $782.6 \pm 141.7 /$ 月， $\mathrm{P}=0.463$, Student $\mathrm{t}$ 検定).

\section{脳血管内治療の内訳}

脳血管内治療の種類による内訳は Fig. 1. 不在時には動 脈瘤コイル治療の割合は低いが, thrombolysis, 動静脈瘻 (arteriovenous fistula: 以下 AVF), 腫瘍の塞栓術など open surgeryで補えない治療分野の割合が大きくなって いた. 

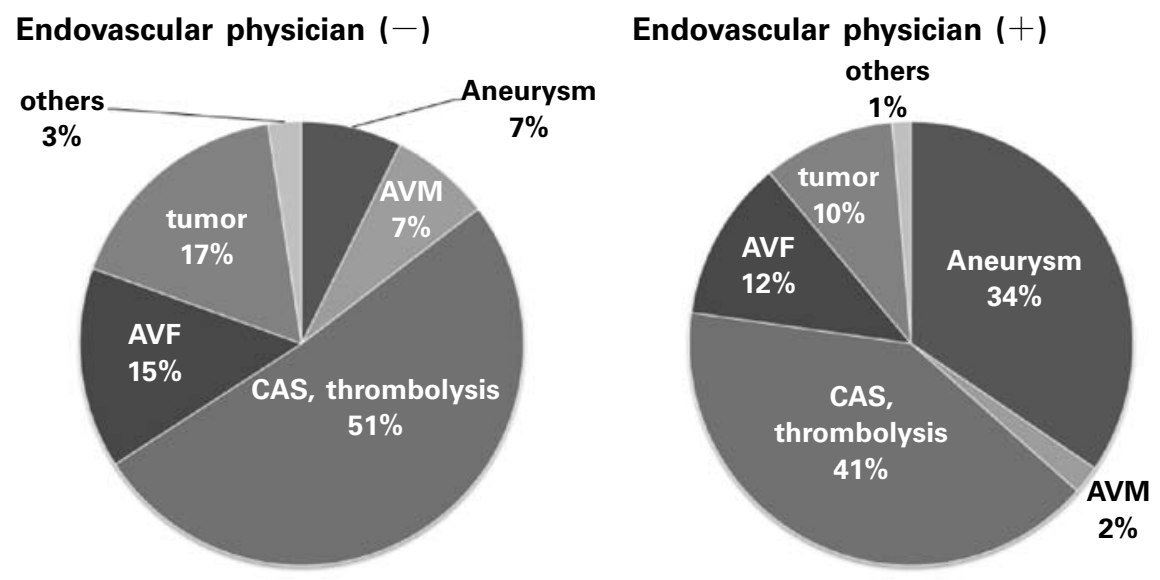

Fig. 1 Types of endovascular treatment with and without endovascular physician.

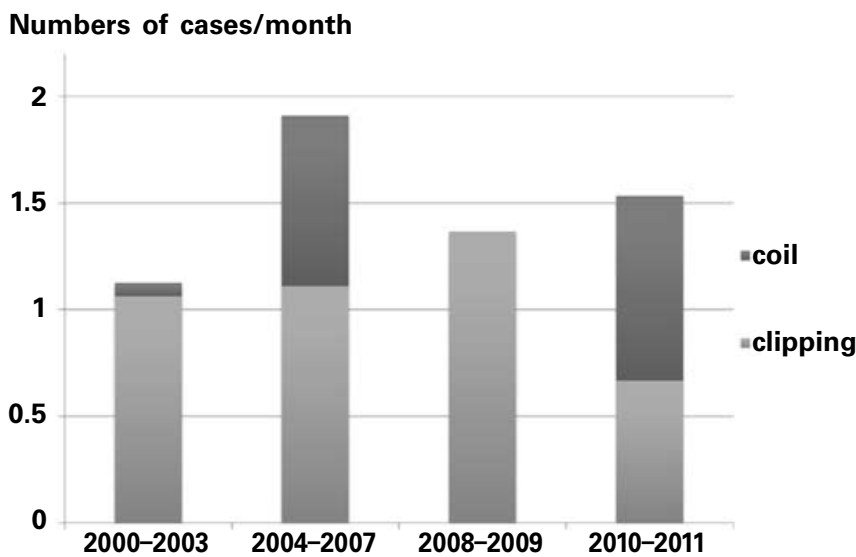

Fig. 2 Number of operations for cerebral aneurysms per month (The period 2004-2007 and 2010-2011 are with endovascular physician).

\section{動脈瘤治療の検討}

当科におけるクリッピングコイル両治療法合わせた全動 脈瘤治療の推移を血管内治療医の有無により4つの期間に 分け検討した(Fig. 2). 期間ごとの症例数に上下の波が あった $(\mathrm{P}=0.0016$, single-factor ANOVA). 2004 年から 2007 年の時期だけ有意に多かった理由は不明だが，全脳 動脈瘤治療数は Table 1 で示したように血管内治療医が 勤務していた時期に多かった.

脳動脈瘤治療を破裂，未破裂動脈瘤で比較すると，血管 内治療医の有無にかかわらず，両者の割合に変わりはな かった(Fig. 3).

動脈瘤の部位の分布については 2 群間で変わりはなかっ た. 不在時には内澒動脈と, 後方循環に限定されて血管内 治療が行われていた。しかし，在籍時には前交通動脈瘤な どにも脳血管内治療が適応されていた(Fig. 4).

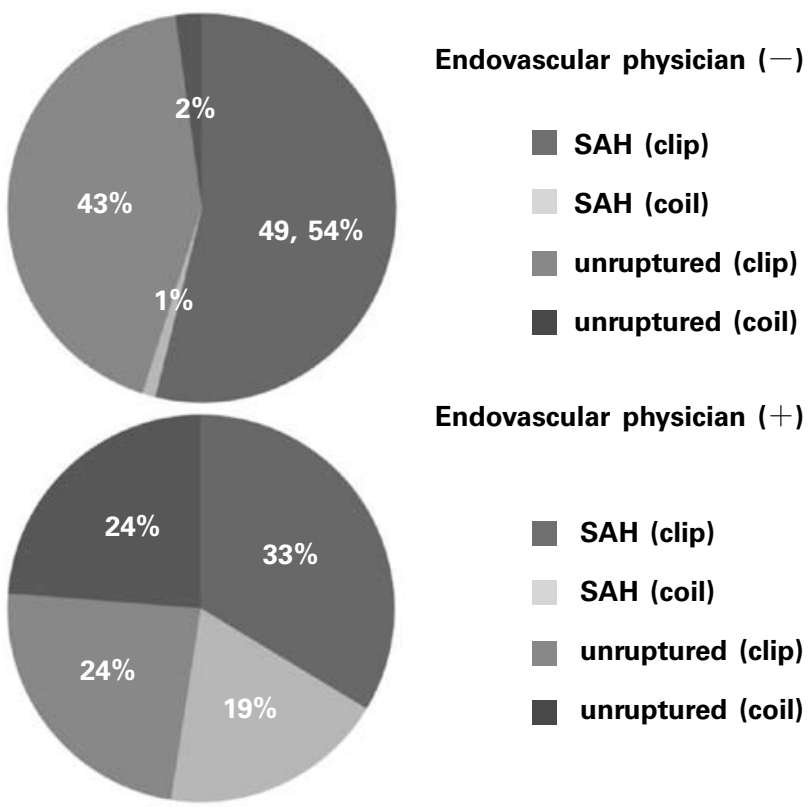

Fig. 3 Number of operation for ruptured and unruptured aneurysms.

\section{治療時間の比較}

治療時間の比較。平均治療時間は脳動脈瘤コイル塞栓術 で $2.29 \pm 0.76$ 時間, CAS で $1.64 \pm 0.64$ 時間, clipping は $7.97 \pm 2.39$ 時間, 内澒動脈内膜剝離術 (carotid endarterectomy：以下 CEA)では $5.03 \pm 1.43$ 時間であった．頚部 内頚動脈狭窄症, 脳動脈瘤治療とも脳血管内治療時間の方 が短かった（ともに $<<0.0001$, Student t 検定）（Table 2).

$$
\text { 考察 }
$$

ISAT studyは，破裂動脈瘤治療における coil 治療の有 用性を証明した ${ }^{8)}$. 日本でもこれら evidence を受けて, メ ディアなどで取り上げられることも追い風となり coil 治療 

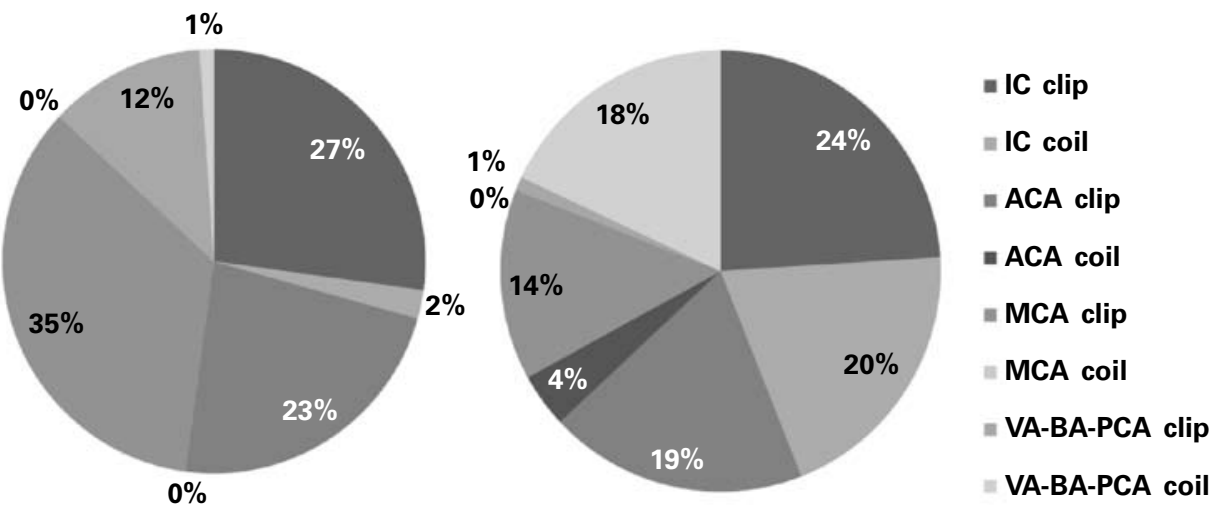

Fig. 4 The percentage of site and treatment of cerebral aneurysm.

Table 2 Treatment procedure times for clipping, coil, CEA and CAS

\begin{tabular}{ccc}
\hline & $\begin{array}{c}\text { Treatment procedure time } \\
\text { (hour) }\end{array}$ & $\mathrm{p}$ \\
\hline clipping & $7.97 \pm 2.39$ & $\mathrm{p}<0.0001$ \\
\cline { 1 - 2 } coil & $2.29 \pm 0.76$ & \\
\hline CEA & $5.03 \pm 1.43$ & $\mathrm{p}<0.0001$ \\
\hline CAS & $1.64 \pm 0.64$ & \\
\hline & & Student $t$
\end{tabular}

症例数を増やしてきた，治療法としてエビデンスを得たこ とで, これまで coil 治療が行われてこなかった地域でも, 患者側から希望が増加したと思われる。

今回の対象は 10 年間超の期間を脳神経外科手術数, 入 院患者数で検討した．全体として，入院患者数，手術数も

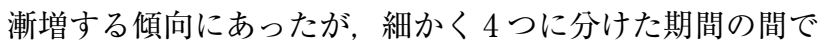
は全手術数, 入院患者数に有意差なく改めて脳血管内治療

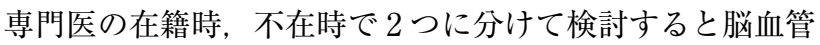
内治療専門医がチームに加わった時期に, open surgery が減少することなく血管内治療数のみならず総手術数も増 加していた。この症例数増加には，単純に治療時間が短く て済む物理的理由のほかにも，いくつか要因が考えられ る.一般的な高齢化に伴うくも膜下出血数自然増, MRI 普及に伴う未破裂動脈瘤発見数の増加のほかに，血管内治 療法が血管障害のみならず脳腫瘍塞栓術などの補助的治療 が行えること. 脳血管内治療のかかわる分野は, 脳動脈瘤, 頚部内頝動脈狭窄症のほか, 脳動静脈奇形, 春椎を含む硬 膜動静脈瘰など多岐にわたること。この地域には他施設に 脳血管内治療医がいないことも当施設症例増加の要因の可 能性が考えられる．両治療の治療成績も関与すると考えら れるが，この期間で大きな合併症もなく，大学病院という 性質上在院日数も非常に短いことより今回の検討ではそれ
ぞれの治療成績は検討対象に含めなかった．同期間の入院 患者数も検討したが，定期的に病棟編成見直しにより， ベッド数が短期間で調整が繰り返されたためか, 一定の傾 向は認めなかった。

治療の効率化や経済性を検討した報告として, 脳動脈瘤 治療の coil 塞栓術は clipping と比較し入院期間が短く, 入 院費用に関しては低かったと報告されている われも手術と入院患者の保険請求額も検討したが, 計算根 拠となる診療点数がたびたび大幅に改定され，診療科の activityの評価対象とはならないと判断した.

破裂脳動脈瘤に対する脳血管内治療に関しては，再発や 再出血の頻度がやや高いことなど6)8 まだ改善すべき余地 があるが, VRD (vascular reconstruction device) ${ }^{2) 7}$ や FD (flow diverter)などまったく新しい deviceが次々に 考案され，今後もさらなる成績向上が期待できる ${ }^{3)}$. さら に急性期脳梗塞の再灌流治療の際に t-PA（tissue-plasminogen activator)静注のみでなく, 脳血管内治療を用いた MERCIリトリーバー (Concentric Medical Inc, Mountain View, California, USA) ${ }^{10) 11}$ や Penumbra System (Penumbra Inc. Alameda, California, USA ${ }^{12}$ などを用い た局所再開通療法が注目されるなど対象疾患の拡大も期待 される。

AHA (American Heart Association)はくも膜下出血の 治療に関し，施設として clip と coil 治療の双方の治療可 能なチームの必要性を明記した(クラス IIa, Evidence Level B)。術者養成に扔いては，脳血管内治療医を作る 厳格かつ支援的プロセスが専門医制度の中に確立されてい $る^{5)}$. 今後も開頭手術, 脳血管内治療の両治療法を維持し ていくことが必要であるが，広義の脳外科医育成の観点か ら, 将来的には単一施設でより多くの症例を持ち, どちら かの治療に偏ることなく両治療医を育成していくことが重 要と思われる. 


\section{結＼cjkstart語}

本研究の結果は, 高齢化に伴うくも膜下出血数自然増, MRI 普及に伴う未破裂動脈瘤発見数の増加, さらに周辺 医療施設の活動状況の変化などに少なからず影響を受けて いると思われるが，血管内治療医在籍期間は非在籍期間に 比べ総血管障害治療数, 総手術数が多かった. 脳血管内治 療医の存在は治療時間の短縮などの効率化とともに, 脳神 経外科の治療実績の向上にも寄与する可能性が示唆され た.

\section{文献}

1) Bederson JB, Connolly ES Jr, Batjer HH, et al: Guidelines for the management of aneurysmal subarachnoid hemorrhage: a statement for healthcare professionals from a special writing group of the Stroke Council, American Heart Association. Stroke 40: 994-1025, 2009

2) Bendok BR, Parkinson, RJ, Hage ZA, et al: The effect of vascular reconstruction device-assisted coiling on packing density, effective neck coverage, and angiographic outcome: an in vitro study. Neurosurgery 61: 835-841, 2007

3) Byrne JV, Beltechi R, Yarnold JA, et al: Early experience in the treatment of intra-cranial aneurysms by endovascular flow diversion: a multicentre prospective study. PLoS One 5(9): e12492, 2010

4) Hoh BL, Chi YY, Lawson MF, et al: Length of stay and total hospital charges of clipping versus coiling for ruptured and unruptured adult cerebral aneurysms in the Nationwide Inpatient Sample database 2002 to 2006. Stroke 41(2): 337-342, 2010

5) Hyogo $T$, Taki W, Negoro M, et al: Japanese society of neuro-endovascular treatment specialist qualification sys- tem. Six years' experience and introduction of an animal model examination. Interv Neuroradiol 14(3): 235240, 2008

6) Johnston SC, Dowd CF, Higashida RT, et al: Predictors of rehemorrhage after treatment of ruptured intracranial aneurysms: the Cerebral Aneurysm Rerupture After Treatment (CARAT) study. Stroke 39(1): 120-125, 2008

7) Mocco J, Snyder KV, Albuquerque FC, et al: Treatment of intracranial aneurysms with the Enterprise stent: a multicenter registry. J Neurosurg 110(1): 35-39, 2009

8) Molyneux AJ, Kerr RS, Birks J, et al: Risk of recurrent subarachnoid haemorrhage, death, or dependence and standardised mortality ratios after clipping or coiling of an intracranial aneurysm in the International Subarachnoid Aneurysm Trial (ISAT): long-term follow-up. Lancet Neurol 8(5): 427-433, 2009

9) Molyneux AJ, Kerr RS, Yu LM, et al: for the International Subarachnoid Aneurysm Trial (ISAT) Collaborative Group. International Subarachnoid Aneurysm Trial (ISAT) of neurosurgical clipping versus endovascular coiling in 2143 patients with ruptured intracranial aneurysms: a randomised comparison of effects on survival, dependency, seizures, rebleeding, subgroups, and aneurysm occlusion. Lancet 366: 809-817, 2005

10) Smith WS: Safety of mechanical thrombectomy and intravenous tissue plasminogen activator in acute ischemic stroke. Results of the multi Mechanical Embolus Removal in Cerebral Ischemia (MERCI) trial, part I. AJNR Am J Neuroradiol 27(6): 1177-1182, 2006

11) Smith WS, Sung G, Saver J, et al: Mechanical thrombectomy for acute ischemic stroke: final results of the Multi MERCI trial. Stroke 39(4): 1205-1212, 2008

12) Tarr R, Hsu D, Kulcsar Z, et al: The POST trial: initial post-market experience of the Penumbra system: revascularization of large vessel occlusion in acute ischemic stroke in the United States and Europe. J Neurointerv Surg 2(4): 341-344, 2010 